\title{
SELECTED DAYS
}

\section{Raymond John de Borja radeborja@gmail.com}

\section{About The Author}

Raymond John de Borja is from Pateros, Metro Manila. His book of poems and collage, they day daze, is forthcoming from High Chair. 


\section{December 27.}

TODAY I ATTEMPT SOMETHING OF A JOURNAL, a tagebuch, a sleep diary. I would like to have something with which to work with and mark by days.

I am thinking about music and why "to understand music" does not make sense in the same way that "to understand instructions" or "to understand a novel" does. In thinking about what it means "to understand music," I find the term abstract quite useful; not abstract when used pejoratively to describe incomprehensible mishmash, or to simply mean generic/general, but abstract meaning non-referential: where meaning emerges mainly from other than reference-for example, from the relationship among notes, rhythm, scale, color.

$*$

Some notes on Gordon Matta-Clark's and Richard Serra's: while both works allow for a "geometric" experience of space, Serra works with pure/asocial formslines, planes, curves; while one can say of Matta-Clark that he works with "social" forms-lines, planes, curves abstracted, for example, from a condemned building.

From an engineering perspective, these asocial forms are harder to re-produce.

$*$

white overheard

song overhead

whence, when, when sung

$*$

One begins to understand composition. Today, I see again a picture of what a few days ago I thought was a plastic bag floating in the afternoon wind, and casting its shadow on the asphalt ground.

Looking at it again, this time closely, I see that it is a window. The plastic bag is not a plastic bag at all, but a flimsy curtain. How had this detail so easily escaped me? 
I am reminded of Andrew Wyeth's curtain in Wind from the Sea. The beautiful sense of dislocation effected by the transparent curtain in mid-flap, in the foreground, carrying with it the slightly fuzzed landscape in the background.

The experience of being in a house.

I am thankful for windows. 


\section{February 26.}

To invent is to present the new as something useful. Thinking in this light, and thinking that utility is a domain of prose and not of poetry, then the new in poetry is not an invention. Jack Spicer takes this further when to a dead Federico Garcia Lorca, he writes, "Prose invents-poetry discloses." Poetry as disclosure-was Spicer hinting at the Heideggerean aletheia?

Yet, we must be wary too of disclosure. While one has to move from mere appearances to access being, this access, as aletheia (disclosure), Hannah Arendt observes, is still conceivable as a form of appearance. Always then, we merely approach and approach the metaphysical cloture.

To not do anything but approach thing music the rough outline the grass strains toward the simple present

Today, I read again Jack Spicer's letters, and am again fascinated by their formal beauty-in After Lorca, how the letters become a vehicle for all the beautiful rhetoric that Spicer wants rid of his poems; in Letters to James Alexander, how a you is made manifest through the sheer intimacy and specificity of address.

In Badiou, the new is something that the existing language cannot yet describe. Taking from Heiddeger, he defines the truth as "something new;" as something ushered in through a rupture in the logic of being and appearance, a rupture which he calls an event, recognizing that this "naming of an event or of the evental presence is itself poetic."

$*$

Dear Jean,

I am writing to you because this pastoral needs another person. We have leaves already and the guests have left. When will you pick up the PVC, the trees, the ants on a log? This is our invention, yet men die miserably, everyday, for lack of what is not found there. 


\section{May 14.}

There are two easy ways out when dealing with questions on the authenticity of the experience of art: the romantic-the cloying notion of 'real' art as an 'expression' of the self and so, as a given, capable of 'speaking' to other selvesand the sociologic - art as nothing more than a product of social relations. Yet neither paradigm seems to me generative (with generative thought being, in my practice, a necessary condition for the production and thinking through of art). It is only through a disregard of the many discourses on the self that we can return to the romantic (is it hope that drives us to want such a return?); and the sociologic, more a realm of the quantifiable than of thought, cannot offer a space that makes a hopeful thinking for and of authenticity and of art possible.

Perhaps Jean-Luc Nancy through his book Listening, offers not a way out but a clearing of sorts which is capable of making generative again the discussions on the authenticity of the experience of art.

Nancy, and here maybe indirectly addressing Bela Bartok's statement that "those who do not know how to read or play music cannot really listen to it," asks, "If someone listens to music without knowing anything about it-as we say of those who have no knowledge of musicology [...], is it possible that he is actually listening to it, rather than being reduced to hearing it?"

While recognizing that "technical apprehension and sensory apprehension" do "strengthen" and "sharpen" each other, in Listening, Nancy discusses music as that which makes possible a sonorous place where the art object and the perceiver are no longer held through a simple subject-object relationship. The sonorous place is where a subject, listening, is referred back to itself not as object, but as a listening subject.

A note outside notational space is time. 


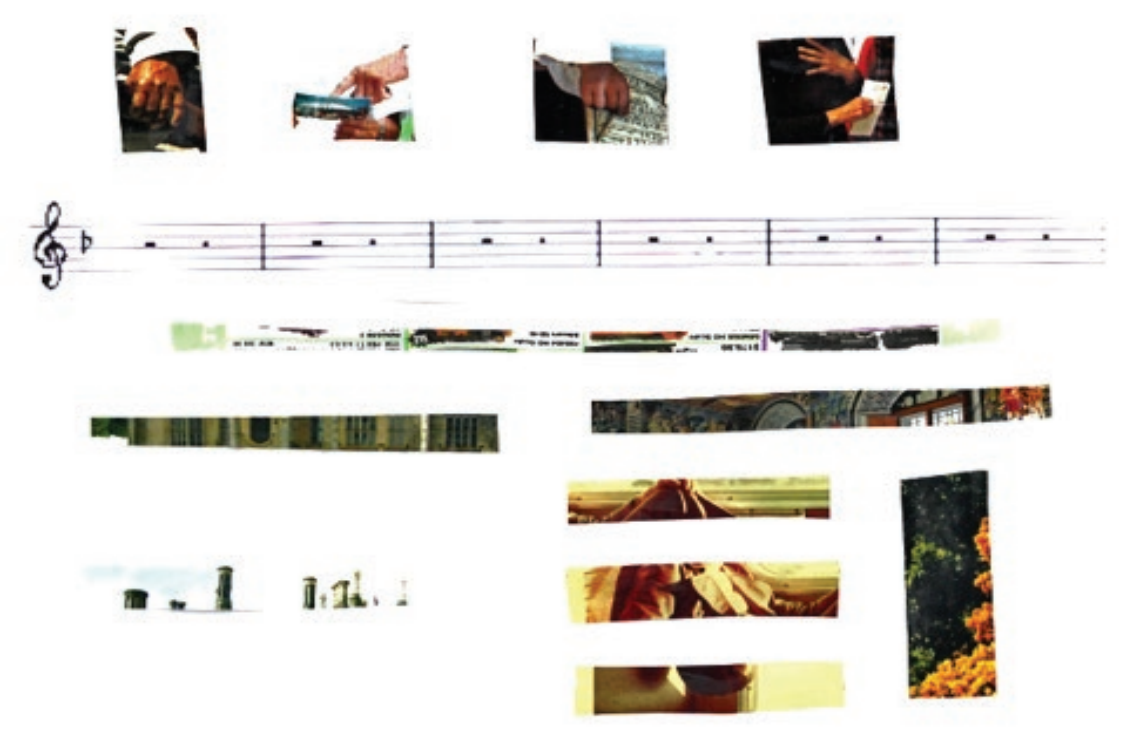

$*$

Notes on two possible sutures for image and sound:

1. Toru Takemitsu directing Masahiro Shinoda to cut scenes that do not work well with the score. Shinoda to Takemitsu: "But when I heard that Turkish flute music at the mix, I was amazed. You were right, this is how the film should end."

2. John Zorn expressing his fascination for Carl Stallings's scores for 30s/40s Bugs Bunny cartoons: "He (referring to Stallings) was dealing with an image and trying to sync music with the image. Take the image away and you're dealing with something that doesn't make musical sense."

The sound of a yellow line

The string section accompanies the sand

Through the megaphone, his musings

Wind-wound 


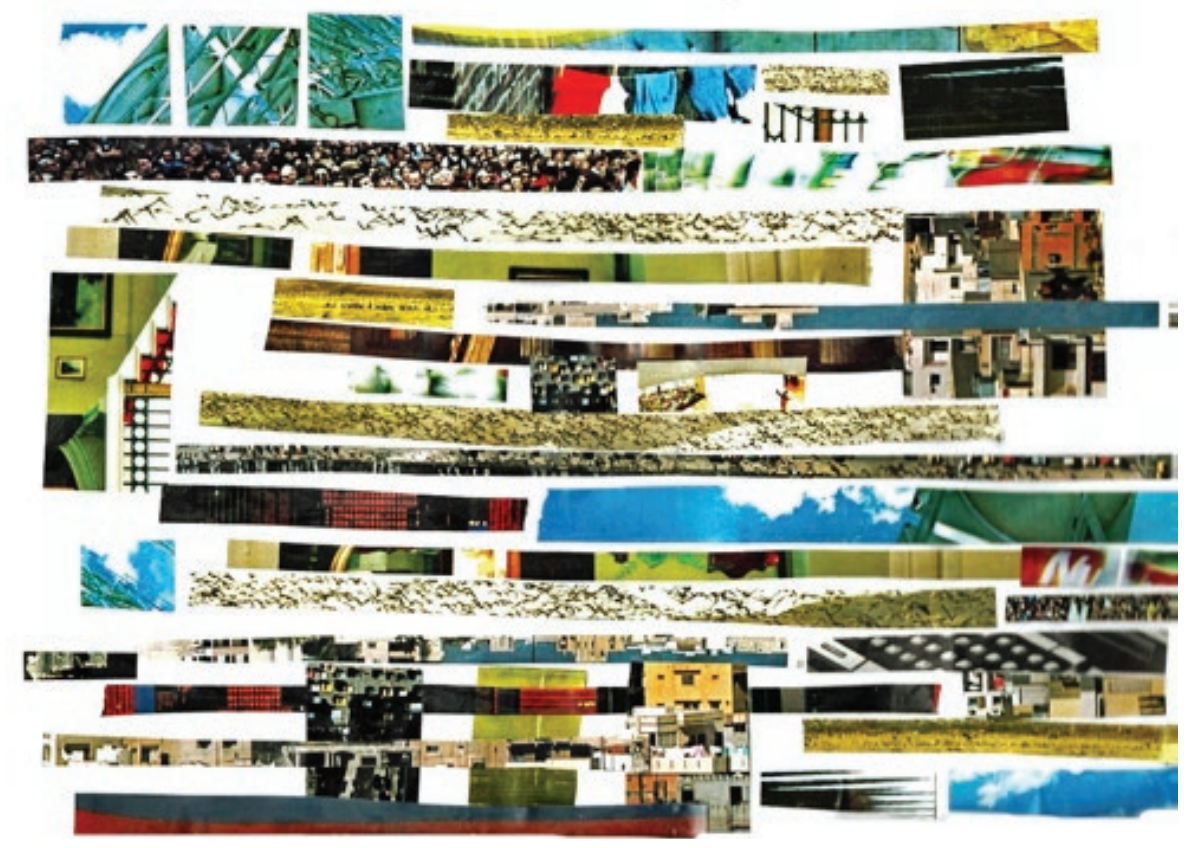

Kritika Kultura 20 (2013): -364

(c) Ateneo de Manila University

<http://kritikakultura.ateneo.net> 


\section{May 27.}

In the opening scene of The Face of Another (directed by Hiroshi Teshigahara, music by Toru Takemitsu), we face the faces in a crowd; the music is waltz; it is a fascinating scene. What binds the music to the image is not atmosphere but the movement of a crowd. The scene is a dance

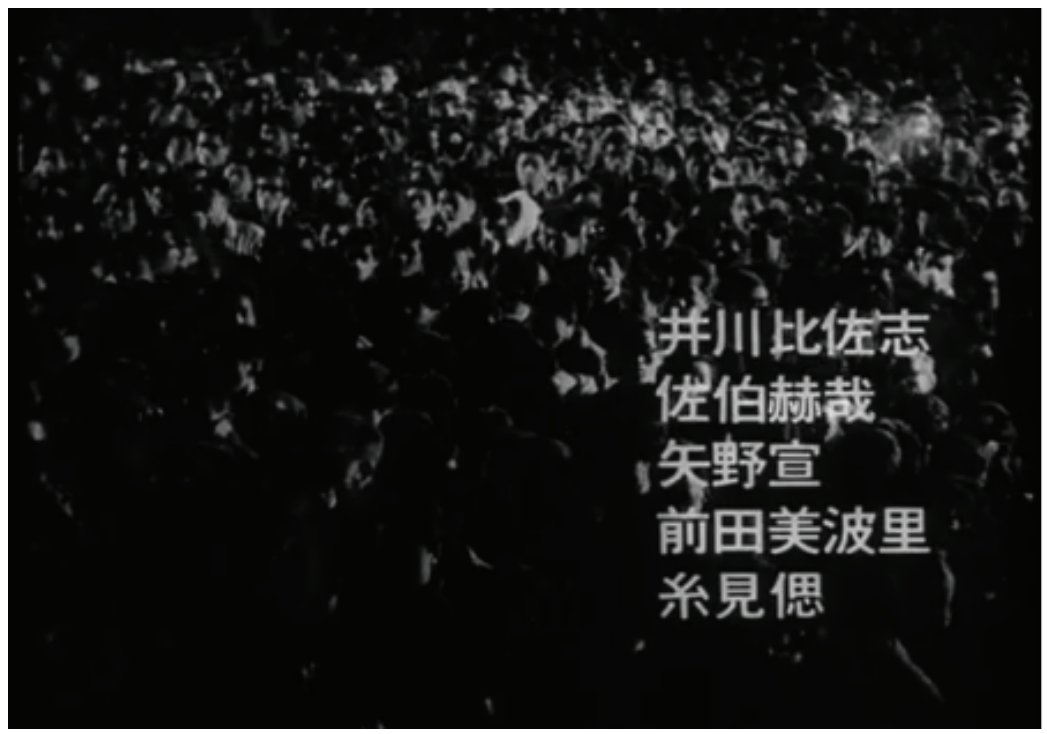

Image from The Face of Another - directed by Hiroshi Teshigahara

parts bear to one another

a hair's

breadth a scant

explanation

countersunk

yet altogether

fall

grasshoppers from a

tower, a prodigious number

of ants,

or preferably of glass

accurately tuned 
"[F]aced with the voice, words structurally fail," Mladen Dolar writes in A Voice and Nothing More. The project then is not description; instead, an enabling of experience. In a movement towards sound, images become lines, literally:

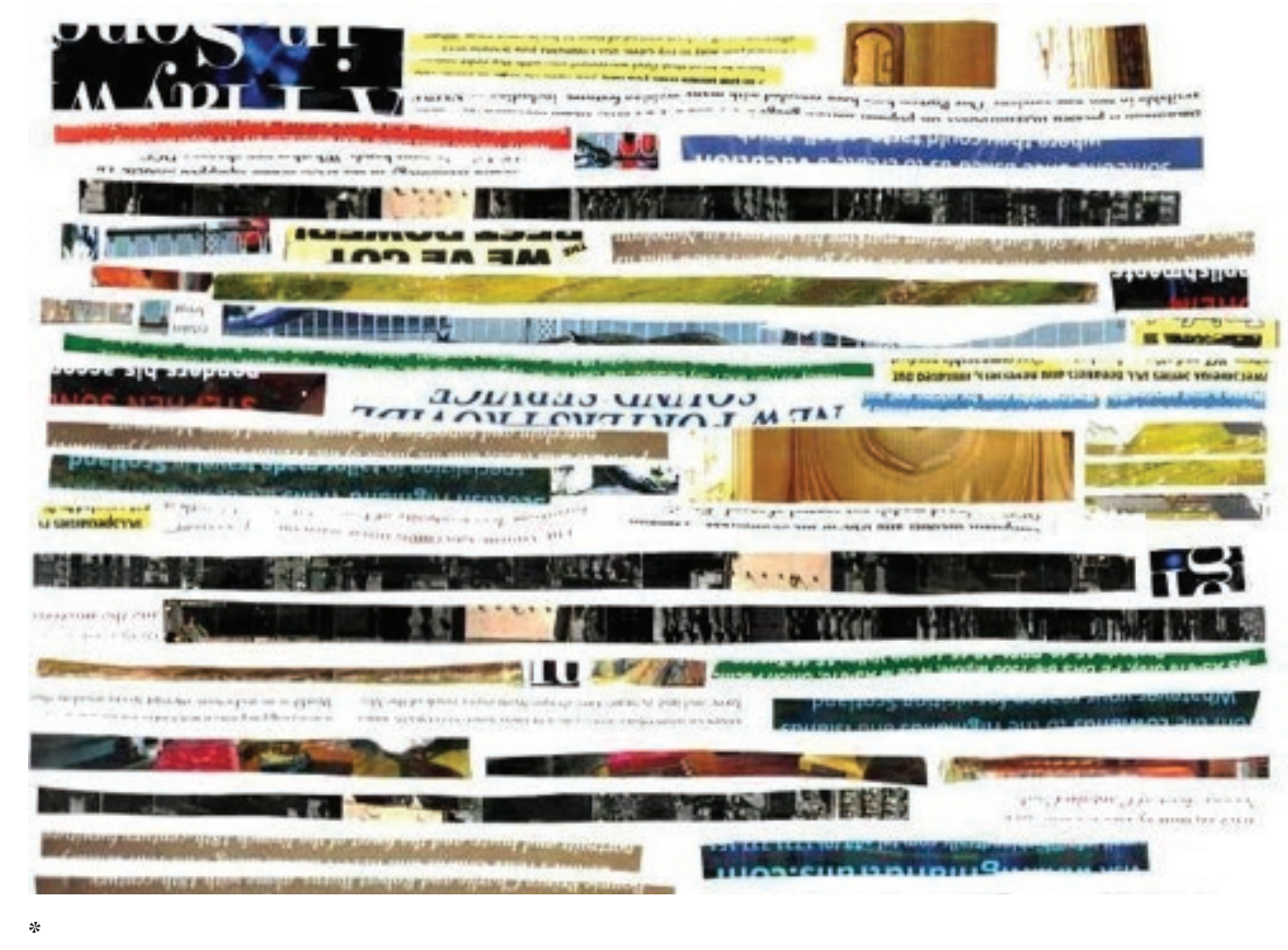

By the third part the bear, finally, comes out of its cave. "Finally" we say to one another-missing boredom by a hair's breadth. Not a hare's breath-the hare has been put to jail for its scant explanation. Yet we thank it for its monologue, which made us look up countersunk. All together now: countersunk.

Grasshoppers fall from a jumping tower. A prodigious number of ants climb the hopping grasshopper tower. We want to catch it with a net, preferably of glass, hurled from a fishing rod, accurately turned. 


\section{June 10.}

More than its regard for cadence, breath, and sound, and how these are 'notated' in a poem via lineation, the spirit of projective verse, and I take spirit to differentiate between a formal fad and an enduring poetic value, is its foregrounding of a poem as a field of perception via an attention to the poem's units of composition. Today, rereading Stephane Mallarme, in the essay Limited Action, describe the poem as being "gifted only with a feeble power," and advise the poet to "perjure [his] verse," I turn to the 'spirit' of projective verse as that which gives the contemporary lyric poem its potency-as a possible space not only for the critique of 'spectacular' modes of perception, but also for the creation of alternatives to the spectacular mode.

Away from the spectacle, in a movement towards sound, the aural imagination of place:

Fray was the name where we came to next. Might've been a place, might not've been a place but we were there, came to it sooner

than we could see... Come to so soon, it was a name we stuck pins in hoping we'd stay. Stray was all we ended up with. Spar was another name we heard

it

went by... Rasp we also heard it was

called... Came to it sooner than we could see but soon enough saw we were there. Some who'd come before us called it Bray... Sound's own principality it was, a pocket of air flexed mouthlike, meaning's mime and regret, a squib of something said, so intent it seemed.

(from Song of the Andomboulou: 50 by Nathaniel Mackey) 
In a movement towards sound, the term abstract is useful-where meaning is produced from other than reference. In the sonorous place (sound's principality), meaning is consistently deferred-always towards a suggestion of meaning (meaning's mime), yet never fully crystallizing (meaning's regret). Fray-strayspar-rasp-bray-words functioning outside their lexical definition, and standing in for place, where sound is so persistent, so intent it/ seemed.

In section 15 of The Work of Art in the Age of Mechanical Reproduction, Walter Benjamin on the phenomenology of buildings writes: "Buildings are appropriated in a twofold manner: by use and by perception —or rather, by touch and sight;" noting that because buildings (architecture) are spatial (and not merely visual) constructs, purely optical means, i.e. "attentive concentration," will not suffice to undertake their appropriation. Benjamin notes as well how we can take the appropriation of buildings as instructive of the kind of attention required to tackle the problematic of disinterested modes of perception: "the tasks which face the human apparatus of perception at the turning points of history cannot be solved by optical means, that is, by contemplation, alone. They are mastered gradually by habit, under the guidance of tactile appropriation." 
Staying in the house, what I see is not a building but a room with Yellow Tulips

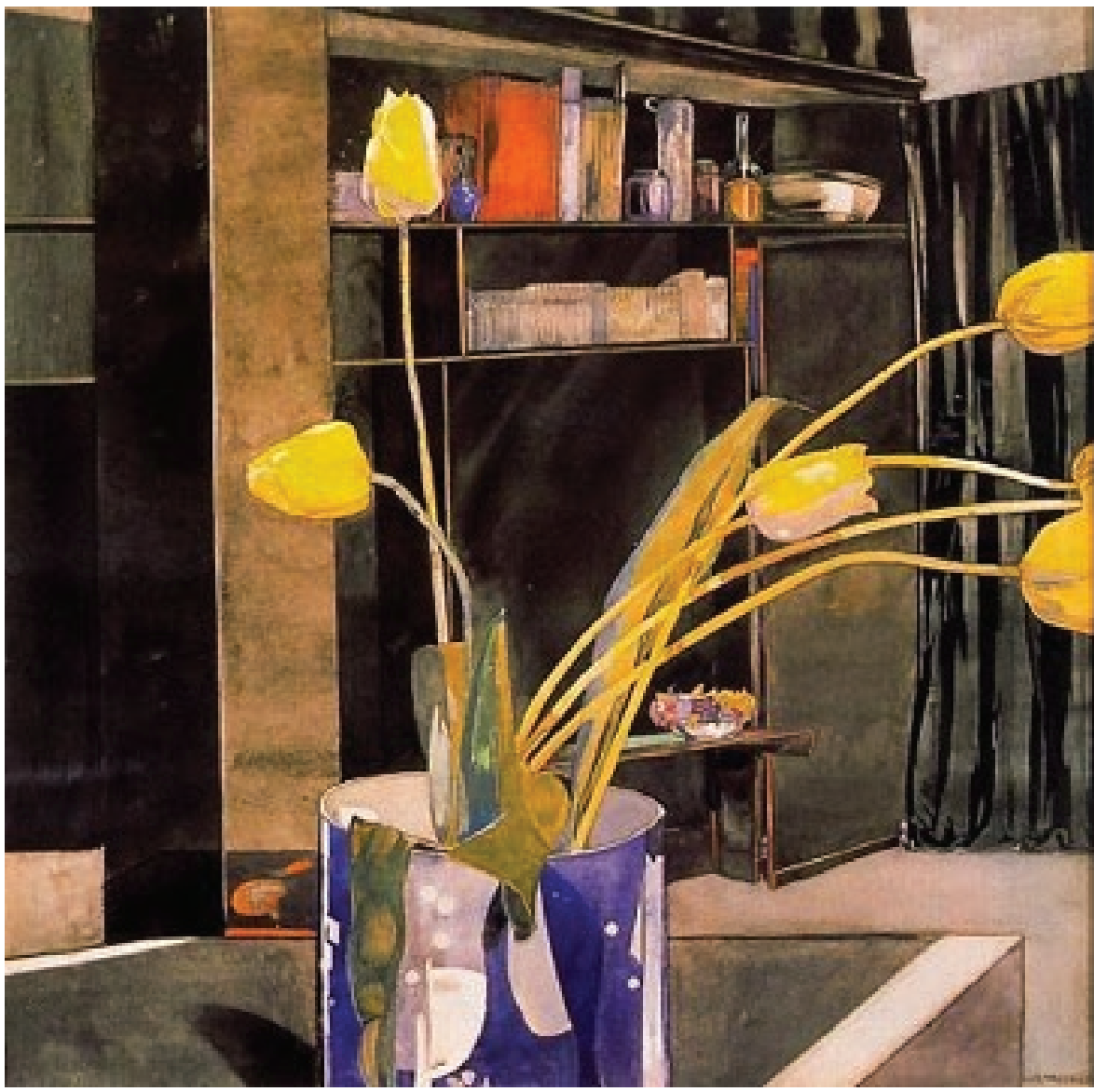

Yellow Tulips, 1923, Charles Rennie Mackintosh

This room like many other rooms is comprised of planes. One creased plane is the curtain. The plane-curtain is creased by rough swaths of white paint on black. Yellow grows from the paint can as tulips. The tulips, each takes a different direction, each to its own source of light. 


\section{November 18.}

Today I am thinking of a long beautiful line, and I am thinking an affect can distribute attention, in the same way that the city architecture does not hold my attention but lays it on several glass windows with the gridded sky. Longing for a horizon line, where glint-like, fishing boats bob up and down to bird calls, the shifting surface of attention, in what ways do we resemble architecture but are not it, to be an entire window? Here the category beautiful things can be used for things that shift the direction of a line towards a newfound attentiveness, which for instance is the unfamiliar familiar door knob sheen tree light afternoon. So when someone says, today is a beautiful day, we can build her a story where everything goes her way, or we can build her a morning she wakes up to things that in some morning may have caught our attention: sound frame thing music night timbre.

\section{Sound Prop \#1: Sound Frame}

She leans at a big window looking over Rue Rousseau. A tiny cafe spills out onto the street, runs past droves of arriving concert-goers, and heads for the theater. Music continues. The clock hands its share. Signs everywhere of, and the sound slides. They are making an appointment. So we walk in a garden of trumpets, and smoke, and knocks on doors, to the sound of the market before the market, static leaves. We are, our faces, found by footsteps.

$*$

Sound Prop \#2: Thing Music

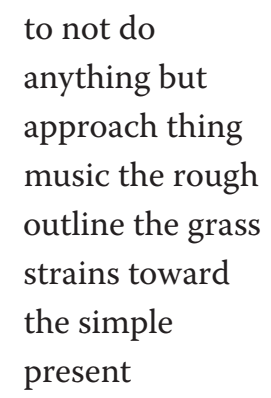


The music is her temperament, writing letters as Susan.

\author{
Sound Prop \#3: Night Timbre
}




\section{December 9.}

Alain Badiou re-presents the Platonic banishment of the poem and offers us a reversal. In Plato, the poem is differentiated from the matheme through the dialectic of the sensible and the intelligible. The poem being "a form of thought that is inseparable from the sensible," while mathematics being a "thought [that is] immediately written as thought;" hence, "poetry [as] thought that is not a thought, a thought that is not even thinkable."

Yet the modern poem has an undeniably "intelligible vocation." Recognizing that the poem's presentation of the sensible does not necessarily place it in opposition to the intelligible/thought, Badiou, in discussing the disjunction between the poem and the matheme, turns away from the Platonic dialectic and moves towards the poem's and the matheme's Real-the real of the matheme being the consistency of language (the necessity of consistency for mathematics to operate as mathematics), the real of the poem being the power of language (the impossibility of the metapoem, the powerlessness of the poem to name its power). As such, in Badiou, both poem and matheme become necessary conditions for the thinking of being, event and truth-the essentially poetic activity of the naming of an event which in turn ushers in truth, and the mathematically rigorous fidelity (a deductive consistency) to this truth. Thinking of Mallarme's A Throw of Dice, Badiou writes: “The poem $[\ldots]$ subordinates sensible desire to the aleatory advent of the Idea. The poem is a duty of thought."

In The End of the Poem, Giorgio Agamben writes of an "essential disjunction" which inheres in the versed lyric poem, between the "semiotic event" (sound/ repetition of a sound) and the "semantic event" (sense). Perhaps, it is in this essential space of non-coincidence where the "aleatory advent of the Idea" can occur in the lyric poem, like

Like the ghost of a woman from ruin

to doors with one pair of shoes

in a drenching rain

or when a spirit in bird-form hits the glass

I waved farewell by the lash

of my eyes, to say goodbye

to romance-once-and much time passed

(from Lines out to Silence by Fanny Howe)

Kritika Kultura 20 (2013): -364

(C) Ateneo de Manila University

<http://kritikakultura.ateneo.net> 
In Agamben, this disjunction, which makes a verse a verse, poses a paradoxical identity crisis for the poem when the poem ends, when sense (normally through the end-stopped line) finally coincides with sound. Of the ending of the poem, Agamben quotes Dante on the canzone: "The ending of the last verses are most beautiful if they fall into silence together with the rhymes."

But it is possible to frame this falling into silence as a non-knowing, or as a nonclosure (thinking of Keats's negative capability, or of Hejinian's rejection of closure) where sound ends but does not necessarily give in to an understanding of what the poem means, but instead ends with an invitation to re-enter and experience again the poem's movement which is also the poem's meaning.

The ruin-rain glass-lash where much time passed.

\section{To Philip Glass}

The first beams of the sun are evidently copies

Time interspersed among the engines and ambient chatter

This is how time sounds like, this day: again and again, her footsteps with the flowers, morning drawn out in the space of a street, again and again, sounds like this day, at the speed of ambient chatter And Glass-like fills the time with buckets and buckets of flowers I trace the engines and flowers, and her, again and again till the morning is drawn out fully at the speed of ambient flowers

A day is composed of several lines. One composes a day through several lines. Several lines compose a day. The last lines of a daybook fall into a day. A note falls in time

\section{Sound Prop \#4: Time}




\section{December 26.}

A day does not come together except under the mark of a day. A year is not an accumulation of days, but a view of the several lines opened up by several days. In essaying the days through notes on the arts, I reach the fact of non-coherencethere are several days. Composition here, then, is a selection of days, which is also to say that composition constitutes an ethics; we choose the days. In a state of the arts, where we are presented with several binary opposites, it is important to choose a multitude, a choice that in no way means to choose all. Simone Weil says of the "relative" that it is "not the opposite of the absolute; it is derived from [the absolute] through a relationship which is not commutative." Through Weil, it is possible to think of the absolute not as a law, but as an infinite set of potentialities, and to think of the relative, not as a never-ending series of differentiation where everyone is right, but as an ethical potential, a choice from an infinite set of possibles.

$*$

\section{from A Notebook for Film Music}

We enter a scene as a layer of sound enters the small windowless room as time. Breath slips out of the oboe and is heard as breath while the violin waits. What slips in we call music. The room is made of layers of time shut from the outside time telling us the music itself is time and is a wall. We revise enter. We enter the scene which is sound contingent upon another sound and so on.

His idea of time is regular but he feels it in the room as layers. Trying to locate the sounds, he finds them separable and shifting though the room is always itself and has white walls. A page turns with the piano, and a gasp, before the oboe sustains an expanding note in the room, filling up time.

He goes outside the room from time into the wind and sand. The wind and sand are sounds but are not time. The wind shifts the sand as a sharply drawn bow against the strings of the violin. Heat is nowhere to be heard so it is there as silence. He could still hear the room in the shifting wind, but not as memory, but as one would hear a real present thing, a source-less after-presence, as one sees the sun in the sand after attempting to look at it in the sky.

What then is a day? In journal writing, a day is a multiplicity. Gertrude Stein: "everything is the same except composition and time, composition and the time of the composition and the time in the composition." In a journal, the time of composition and the time in the composition are both days; taking from Stein,

Kritika Kultura 20 (2013): -364

(C) Ateneo de Manila University

<http://kritikakultura.ateneo.net> 
these are separate days. What bind the days together are their movements-each a heterogeneous directionality marked by its movement towards another day. We can choose a day to be our composition as we are composed by days, and, we can choose this relationship to be non-commutative. "We [can] sing to be ourselves tomorrow," borrowing from Lyn Hejinian.

If we say of music that it eludes the present in both its progression and resounding, then we can say of the present that it is located at the end of the music. A long, glaring present in the desert heat. Composition is the experience of duration. An aural imagination of On Kawara's date paintings, and Roman Opalka's number paintings suggests an imagined movement towards a present. We can say of both of them that they are looking for days. We can say of a composition that it fills the present as it defers it. We can say that a journal when offered to a reader must end in we. 


\section{Works Cited}

Agamben, Giorgio. The End of the Poem. Trans. Daniel Heller-Roazen. Stanford: Stanford UP, 1996.

Arendt, Hannah. The Life of the Mind. Ed. Mary McCarthy. Orlando: Harcourt, 1978.

Badiou, Alain. Being and Event. Trans. Oliver Feltham. New York: Continuum, 2007.

--. Handbook of Inaesthetics.Trans. Rodrigo Toscano. Stanford: Stanford UP, 2005.

Benjamin, Walter. Illuminations: Essays and Reflections. Ed. Hannah Arendt. New York: Schocken, 2007.

Dolar, Mladen. A Voice and Nothing More. Cambridge: MIT, 2006.

Heidegger, Martin. Being and Time. Trans. John Macquarrie and Edward Robinson. New York: HarperCollins, 1962.

Hejinian, Lyn. The Book of a Thousand Eyes. Richmond: Omnidawn, 2012.

--. The Language of Inquiry. Berkeley: U of California P, 2000.

Howe, Fanny. Selected Poems. Berkeley: U of California P, 200.

Mackey, Nathaniel. Splay Anthem. New York: New Directions, 2006.

Mackintosh, Charles Rennie. Yellow Tulips. 1923. Private Collection. Lyon and Turnbull. Web. 10 June 2012.

Mallarme, Stephane. Divagations. Trans. Barbara Johnson. Cambridge: Harvard UP, 2009.

Matta-Clark, Gordon. Conical Intersect. 1975. Photograph. Artnet. Web. 27 Dec. 2011.

Nancy, Jean-Luc. Listening. Trans. Charlotte Mandell. New York: Fordham UP, 2007.

Serra, Richard. Torqued Spiral. 2003 - 2004. Guggenheim Museum Bilbao, Bilbao. Guggenheim. Web. 27 Dec. 2011.

Spicer, Jack. My Vocabulary Did This to Me: The Collected Poetry of Jack Spicer. Eds. Peter Gizzi, and Kevin Killian. Middletown: Wesleyan UP, 2008.

Weil, Simone. Gravity and Grace. Trans. Emma Crawford and Mario von der Ruhr. New York: Routledge, 2002. 
Williams, William Carlos. Selected Poems. Ed. Charles Tomlinson. New York: New Directions, 1985.

Wyeth, Andrew. Wind from the Sea. 1948. Private Collection. Artchive. Web. 27 Dec. 2011.

“Enter the Garden: Toru Takemitsu." BBC. BBC. 2008. Web. 14 May 2012.

“John Zorn Documentary." Youtube. 2008. Web. 14 May 2012.

The Face of Another. Dir. Hiroshi Teshigahara. The Criterion Collection, 2007. DVD.

Kritika Kultura 20 (2013): -364

(C) Ateneo de Manila University

<http://kritikakultura.ateneo.net> 